\title{
Perlindungan Hukum Terhadap Penyandang Disabilitas Korban Tindak Pidana Asusila: Studi di Sasana Inklusi dan Gerakan Advokasi Difabel (SIGAB)
}

\author{
Muhammad Bayu Saputro \\ Pengadilan Negeri Lubuk Basung \\ muhammadbayusp@gmail.com
}

\section{Natangsa Surbakti}

Universitas Muhamadiyah Surakarta

natangsasurbakti@gmail.com

\section{Kelik Wardiono}

Universitas Muhammadiyah Surakarta

liekums@gmail.com

DOI: $10.23917 /$ jjr.v10i1.10527

\begin{abstract}
Submission
Track:

Received:

\section{ABSTRAK}

Tujuan: Penelitian ini bertujuan untuk mengetahui penerapan Peraturan Perundang-undangan di Indonesia dalam kasus penyandang disabilitas korban tindak pidana asusila, kemudian perlindungan hukum terhadap penyandang disabilitas korban tindak pidana asusila, serta peran Sasana Inklusi dan Gerakan Advokasi Difabel dalam proses advokasi terhadap korban difabel.
\end{abstract}

11 Maret 2020

Final Revision:

11 Juni 2020

Available online:

31 Juli 2020

Corresponding

Author:

Muhammad Bayu

Saputro

muhammadbayusp

@gmail.com

Metodologi: Metode pendekatan yang digunakan adalah pendekatan nondoktrinal kualitatif. Jenis penelitian yang digunakan adalah penelitian deskriptif. Penelitian ini menggunakan sumber data primer dan data sekunder. Metode pengumpulan data yang digunakan adalah studi kepustakaan, dan wawancara.

Temuan: Terdapat perbedaan penerapan Peraturan Perundangundangan terhadap kasus penyandang disabilitas korban tindak pidana asusila (perkosaan dan pencabulan) antara korban dewasa dengan korban anak. Perlindungan hukum terhadap penyandang disabilitas korban tindak pidana asusila dilakukan melalui pemenuhan hak yang berkaitan secara langsung. Peran SIGAB dalam mendampingi korban difabel meliputi proses litigasi dan non litigasi.

Kegunaan: Pemerintah perlu segera menyusun dan menerbitkan Peraturan Perundang-undangan yang berkaitan dengan Perlindungan Penyandang Dsabilitas, serta tentang Sistem Peradilan Pidana Penyandang Disabilitas.

Kebaruan/Orisinalitas: Penyelenggaraan pendidikan dan pelatihan tentang "Teknis Peradilan Pidana Penyandang Disabilitas Berhadapan Dengan Hukum" bagi Penyidik, Jaksa, dan Hakim dapat menambah pemahaman dan 
pengetahuan para penegak hukum tersebut dalam proses pemeriksaan di setiap tingkatan terhadap penyandang disabilitas berhadapan dengan hukum.

Keywords: Korban difabel, perlindungan hukum, tindak pidana asusila

\section{PENDAHULUAN}

Manusia sesuai kodratnya diciptakan oleh Allah SWT dalam kedudukan yang sejajar. Di dalam kehidupan bermasyarakat terdapat berbagai perbedaan yang didasarkan pada jenis kelamin, warna kulit, suku, agama, budaya, maupun sebagai penyandang disabilitas. Seringkali perbedaan tersebut dijadikan alasan untuk memperlakukan manusia secara berbeda, terutama terhadap penyandang disabilitas. Meskipun memiliki keterbatasan, penyandang disabilitas memiliki hak dan kewajiban seperti halnya manusia normal pada umumnya. Dengan demikian, tidak ada alasan untuk memperlakukan mereka yang mengalami disabilitas secara diskriminatif, terutama bagi penyandang disabilitas yang berhadapan dengan hukum sebagai korban tindak pidana asusila.

Berdasarkan Pasal 1 angka 1 Undang-Undang Nomor 8 Tahun 2016 tentang Penyandang Disabilitas, penyandang disabilitas adalah setiap orang yang mengalami keterbatasan fisik, intelektual, mental, dan/atau sensorik dalam jangka waktu lama yang dapat berinteraksi dengan lingkungan dapat mengalami hambatan dan kesulitan untuk berpartisipasi secara penuh dan efektif dengan warga negara lainnya berdasarkan kesamaan hak.

Keterbatasan-keterbatasan yang dialami oleh penyandang disabilitas dapat dipastikan berdampak pada aktivitas keseharian mereka dalam menjalani kehidupan, baik secara langsung maupun tidak langsung. Hambatan-hambatan yang dialami oleh setiap penyandang disabilitas tersebut berbeda antara satu dengan yang lain, tergantung ragam disabilitas yang dimiliki. Permasalahan yang dihadapi penyandang disabilitas di Indonesia sangat luas dan kompleks karena mencakup berbagai aspek mendasar kehidupan. Terlebih jika penyandang disabilitas dihadapkan pada kondisi sebagai korban tindak pidana. Mereka akan mengalami banyak permasalahan mulai dari tahap pelaporan sampai proses persidangan, aksesibilitas informasi, serta sarana dan prasarana. Selain itu, stigma dari penegak hukum juga menjadi kendala dalam tahap pelaporan adanya tindak pidana. Penyandang disabilitas fisik dianggap tidak dapat membela diri menghindari adanya tindak pidana, kemudian penyandang disabilitas sensorik (rungu, wicara, netra) kesaksiannya dianggap kurang meyakinkan, serta penyandang disabilitas mental dianggap tidak cakap hukum. 
Persoalan tersebut akan menjadi serius apabila hanya dibiarkan saja tanpa adanya tindakan tegas dari pemerintah untuk menempatkan kaum difabel mendapatkan akses publik sebanyak-banyaknya khususnya dalam penegakkan hukum, karena mereka juga bagian dari para pencari keadilan yang dilindungi oleh konstitusi. Undang-Undang Nomor 13 Tahun 2006 sebagaimana diubah dengan Undang-Undang Nomor 31 Tahun 2014 tentang Perlindungan Saksi dan Korban sudah lama diberlakukan dan memiliki tujuan untuk melindungi setiap orang yang menjadi korban dari ancaman untuk menjadi korban kembali, dengan hak-hak yang diberikan seperti mendapatkan penerjemah, petikan putusan, rehabilitasi hingga restitusi. Ratifikasi perjanjian internasional juga telah dilakukan pemerintah yaitu Convention on The Rights of Person with Disabilities (Konvensi Mengenai Hak-Hak Penyandang Disabilitas) dalam Undang-Undang Nomor 19 Tahun 2011 tentang Pengesahan Convention on The Rights of Person with Disabilities (Alfian, 2015). Meskipun berbagai upaya Pemerintah dalam melindungi penyandang disabilitas sebagai korban tindak pidana telah dilakukan, namun dalam praktinya penerapan Peraturan Perundang-undangan tersebut mengalami kendala.

Salah satu potret Peradilan yang tidak fair dan diskriminatif yang menimpa difabel adalah ketika proses Peradilan adalah seringkali penyandang disabilitas dipersalahkan oleh penegak hukum karena identitasnya yang difabel. Dalam perkara pidana, difabel rungu wicara yang menjadi korban pemerkosaan sering disudutkan penegak hukum karena tidak berteriak ketika diperkosa, kemudian difabel netra tidak diproses oleh penegak hukum karena korban tidak bisa melihat pelaku pemerkosaan, selanjutnya difabel rungu wicara ketika proses Peradilan seringkali tidak berfungsi karena menyerahkan proses tanya jawab penyidikannya kepada para penerjemah (Endang Ekowarni 2014).

Pada dasarnya, penyandang disabilitas merupakan bagian dari warga negara Indonesia yang memiliki kedudukan, hak, kewajiban, dan peran yang sama dengan warga negara Indonesia lainnya (Amin and Mustari, 2015). Berdasarkan Pasal 28D ayat (1) UndangUndang Dasar Negara Republik Indonesia Tahun 1945 menyatakan bahwa:

"setiap orang berhak atas pengakuan, jaminan, perlindungan, dan kepastian hukum yang adil serta perlakuan yang sama dihadapan hukum"

Oleh karena itu, perlindungan hukum terhadap penyandang disabilitas korban tindak pidana asusila menjadi hal yang sangat penting, karena dengan adanya perlindungan hukum yang baik maka kepastian hukum juga akan terlaksana dengan baik. Perlindungan hukum tidak sebatas pada proses pelaporan adanya tindak pidana, melainkan sampai pada proses 
persidangan hingga putusan berkekuatan hukum tetap. Putusan yang bersifat menimbulkan efek jera dan adanya rehabilitasi bagi korban akan berdampak baik bagi kepastian hukum kedepannya, serta tidak akan ada lagi kejadian serupa dalam kasus tindak pidana asusila yang melibatkan penyandang disabilitas sebagai korban, atau setidak-tidaknya kejadian tindak pidana asusila yang melibatkan penyandang disabilitas sebagai korban menjadi berkurang.

\section{METODE PENELITIAN}

Metode penelitian yaitu suatu kegiatan ilmiah yang didasarkan pada metode, sistematika dan pemikiran tertentu, yang bertujuan untuk mempelajari satu atau beberapa gejala hukum tertentu dengan jalan menganalisanya (Dimyati\&Wardiono, 2004). Metode pendekatan yang digunakan adalah pendekatan non-doktrinal yang kualitatif. Sumber data terdiri dari data primer yaitu hasil dari wawancara dan data sekunder yaitu bahan hukum primer dan bahan hukum sekunder. Metode pengumpulan data menggunakan studi kepustakaan, dan wawancara, kemudian dianalisa menggunakan metode kualitatif dengan metode berpikir deduktif.

\section{HASIL PENELITIAN DAN PEMBAHASAN}

Penerapan Peraturan Perundang-Undangan di Indonesia dalam Kasus Penyandang Disabilitas Korban Tindak Pidana Asusila

Kejahatan yang dilakukan terhadap penyandang disabilitas sebagian besar tidak terlihat, dan dapat diperkirakan bahwa kejahatan terhadap penyandang disabilitas lebih sering terjadi dari pada terhadap seseorang tanpa kondisi disabilitas (Bryen, dkk., 2003, dalam Reiter et al., 2007). Penyandang disabilitas memiliki resiko besar mengalami kekerasan dari pada seseorang tanpa kondisi disabilitas. Lazimnya, pelecehan seksual terhadap penyandang disabilitas relatif lebih tinggi, terutama terhadap penyandang disabilitas intelektual (World Health Organization, dalam Conroy, 2015). Berikut merupakan gambaran perkara tindak pidana asusila terkait perkosaan-pencabulan terhadap penyandang disabilitas:

\section{a. Gambaran Perkara Nomor 78/Pid.B/2013/PN Ska. dan Perkara Nomor 79/Pid.B/2013/PN Ska}

Persetubuhan dan pencurian dengan kekerasan dalam perkara a quo terjadi pada hari Selasa tanggal 4 Desember 2012 sekitar jam 03.30 WIB. Awal mulanya Agus dan Triyanto berboncengan menggunakan sepeda motor, kemudian saat sampai depan SPBU 
Balapan Agus dan Triyanto bertemu dengan Korban Ica (nama samaran). Selanjutnya, korban diboncengkan ditengah dan menuju ke kuburan Mojo Jebres Surakarta. Saat sampai dikuburan Mojo, korban diajak Triyanto ke tengah kuburan dan terjadi persetubuhan, selanjutnya Agus juga menyetubuhi korban. Setelah itu, Agus dan Triyanto serta korban pergi ke tempat Surya dan Dwi Suhardi yang sudah menunggu di Plaza Palur. Setelah bertemu, selanjutnya mereka berjalan ke ISI II Ringroad Mojosongo Surakarta. Kemudian terjadi persetubuhan lagi oleh Surya dan Dwi Suhardi. Selanjutnya Agus, Triyanto, Surya dan korban menuju ke kuburan Mojo, sedangkan Dwi Suhardi pulang ke rumahnya. Setelah sampai di kuburan, Agus mempunyai ide untuk mengambil dompet milik korban. Selanjutnya korban diajak Agus masuk ke dalam kuburan, Triyanto dan Surya menunggu diluar kuburan. Ketika korban membelakangi Agus, Agus langsung menendang korban selanjutnya dompet milik korban yang diletakkan di atas batu nisan langsung diambil oleh Agus. Kemudian Agus melarikan diri keluar kuburan dan ketika sampai di luar kuburan Agus membonceng Triyanto ke arah Palur.

Hasil dari wawancara, peristiwa yang menimpa Korban Ica terungkap saat Sujito dan Eko (Anggota Kepolisian Sektor Jebres) melakukan patroli di sekitar ISI II Ringroad Mojosongo, Jebres, Surakarta setelah mendapat laporan dari masyarakat bahwa ada 2 (dua) orang laki-laki yang ditarik-tarik oleh seorang perempuan. Kemudian, ketika anggota Kepolisian Polsek Jebres tersebut sampai di lokasi, mereka mendapati seorang perempuan (korban) yang bicara gagu dengan bahasa isyarat menunjukkan bahwa ia telah disetubuhi oleh laki-laki yang ditunjuk korban. Selanjutnya anggota Kepolisian Polsek Jebres tersebut mengamankan korban dan 2 (dua) orang laki-laki ke Polsek Jebres untuk pemeriksaan.

Dalam pemeriksaan, Penyidik mengalami kesulitan berkomunikasi karena korban merupakan penyandang disabilitas rungu dan disabilitas wicara. Masalah tersebut sempat teratasi ketika adik ipar dari Penyidik membantu (sebagai Penerjemah) komunikasi antara Penyidik dengan korban. Namun, ternyata mengalami kesulitan karena bahasa isyarat korban dengan penerjemah berbeda, serta jenjang pendidikan korban hanya sampai kelas 4 SD. Selanjutnya, penerjemah berinisiatif memanggil teman SD korban yang bernama Oki untuk membantu menerjemahkan bahasa isyarat antara korban dengan Penyidik. Masalah baru kemudian muncul ketika Oki yang seharusnya hanya sebagai penerjemah, namun karena Penyidik menyerahkan sepenuhnya masalah komunikasi kepada Oki, 
justru Oki yang menginterogasi korban dengan prasangka buruk, dengan mengajukan pertanyaan "kamu ngapain jam 4 pagi sendirian di tempat itu" dan "kamu perempuan, kok berpakaian seperti itu”. (M.Syafi'i, 2016)

Selain itu, dalam gelar perkara kenyataan bahwa korban dipaksa meminumminuman keras tidak diungkap oleh penerjemah, karena Penerjemah sudah memiliki prasangka buruk terhadap perilaku korban yang dianggap sebagai pekerja seks. Dalam proses penyidikan tersebut, korban juga tidak mendapat pendampingan hukum. Selanjutnya, hasil penyidikan tersebut ternyata menjadi pedoman bagi Jaksa. Awalnya para pelaku dijerat dengan Pasal 289 KUHP (Pencabulan) jo. Pasal 365 KUHP (pencurian dengan kekerasan), namun alat bukti kurang lengkap karena hasil visum et repertum tidak menunjukkan ada luka akibat pemaksaan dan korban dianggap melepas celana dalamnya dan mengambil posisi nungging, tanpa ada paksaan dan pelaku dengan mudah memasukkan alat kelaminnya. Dengan demikian, Jaksa menyusun dakwaan mengenai tindak pidana pencurian dengan kekerasan, yaitu didakwa dengan dakwaan subsidaritas: Primair, Pasal 365 ayat (2) ke-2 KUHP atau Subsidair: Pasal 363 ayat (1) ke-4 KUHP.

Kemudian, pada tahap persidangan karena perkara berubah menjadi perkara pencurian, dan pelaku yang terlibat pencurian adalah Agus, Triyanto dan Surya, maka yang menjadi terdakwa adalah Agus, Triyanto dan Surya, karena Dwi Suhardi tidak terlibat dalam tindak pidana pencurian. Selama diperiksa di persidangan korban didampingi penerjemah disabilitas wicara dari Gerakan untuk Kesejahteraan Tunarungu Indonesia (Gerkatin) Surakarta. Selanjutnya, dalam Putusan Pengadilan Negeri Surakarta Nomor 78/Pid.B/2013/PN Ska. dan Nomor 79/Pid.B/2013/PN Ska., Majelis Hakim menyatakan para terdakwa terbukti secara sah dan meyakinkan bersalah melakukan tindak pidana melakukan tindak pidana pencurian dengan kekerasan sebagaimana dakwaan Primair Pasal 365 ayat (2) ke-2 KUHP, dan menjatuhkan pidana kepada terdakwa dengan pidana penjara selama 10 (sepuluh) bulan.

Penyandang disabilitas sensorik (rungu-wicara) dalam kapasitas sebagai saksi/korban memiliki keterbatasan untuk mengakses proses dan informasi pada tahap pemeriksaan, terutama proses persidangan. Namun, keterbatasan itu bukan menjadi penghalang untuk memperoleh akses keadilan yang sesungguhnya. Keterbatasan berupa tidak dapat berbicara dengan bahasa Indonesia lisan yang baik akan mengalami kesulitan 
saat dimintai keterangan. Untuk menjamin hak penyandang disabilitas rungu-wicara terpenuhi sesuai Peraturan Perundang-undangan, mereka wajib didampingi oleh penerjemah bahasa isyarat yang memadai (Saija, 2017).

Undang-Undang Nomor 13 Tahun 2006 (selanjutnya disebut UU Nomor 13/2006) sebagaimana diubah dengan Undang-Undang Nomor 31 Tahun 2014 (selanjutnya disebut UU Nomor 31/2014) tentang Perlindungan Saksi dan Korban dalam Pasal 5 ayat (1) telah mengatur hak saksi dan korban salah satunya adalah hak "mendapat penerjemah", namun karena dalam ketentuan ayat (2) menyatakan bahwa "hak sebagaimana dimaksud dalam ayat (1) diberikan kepada saksi dan/atau korban tindak pidana dalam kasus-kasus tertentu sesuai dengan keputusan LPSK', antara lain: tindak pidana korupsi, tindak pidana narkotika/psikotropika, tindak pidana terorisme, dan tindak pidana lain yang mengakibatkan posisi Saksi dan Korban dihadapkan pada situasi yang sangat membahayakan jiwanya. Maka, hak korban dalam perkara a quo berdasarkan ketentuan UU Nomor 13 / 2006 tidak terealisasikan dengan baik. (Peristiwa tindak pidana dalam Perkara Nomor 78/Pid.B/2013/PN Ska. dan Perkara Nomor 79/Pid.B/2013/PN Ska. terjadi ketika UU Nomor 31 / 2014 tentang Perubahan atas UU Nomor 13 / 2006 tentang Perlindungan Saksi dan Korban belum diundangkan).

Meskipun mayoritas hak yang diatur dalam Kitab Undang-Undang Hukum Acara Pidana (KUHAP) adalah hak dari tersangka dan terdakwa, pada dasarnya KUHAP juga mengatur hak korban, seperti tuntutan ganti rugi dan mendapat penerjemah, termasuk penerjemah bahasa isyarat. Dalam perkara a quo korban mendapat penerjemah bahasa isyarat pada proses penyidikan sampai dengan proses persidangan sebagaimana diatur dalam ketentuan Pasal 178 KUHAP. Namun, hak mendapat penerjemah yang diperoleh korban pada tahap penyidikan pada dasarnya telah menyalahi aturan dalam KUHAP. Karena wewenang memeriksa korban adalah wewenang Penyidik, bukan wewenang penerjemah. Penerjemah hanya membantu korban dalam memberikan keterangan yang utuh terhadap pembicaraan dan pesan yang disampaikan (Ashar, Ashila, and Pramesa 2019). Dalam hal ini, pembicaraan dan pesan yang disampaikan oleh Penyidik ketika melakukan pemeriksaan terhadap korban.

Terkait dengan Pasal pencurian dengan kekerasan yang didakwakan kepada para terdakwa, hal tersebut terjadi karena Pasal 285 KUHP (perkosaan) dan Pasal 289 (pencabulan) KUHP harus memenuhi unsur "dengan kekerasan atau ancaman kekerasan 
memaksa seseorang", sedangkan dalam pemeriksaan pada tahap penyidikan tidak ditemukan adanya unsur tersebut, serta minimnya alat bukti untuk menjerat para pelaku dengan pasal perkosaan atau pasal pencabulan. Berbeda dengan Undang-Undang Nomor 35 Tahun 2014 tentang Perubahan Atas Undang-Undang Nomor 23 Tahun 2002 tentang Perlindungan Anak, pada Pasal 76D (perkosaan anak) dan Pasal 76E (pencabulan anak) terdapat unsur yang bersifat alternatif yaitu: "melakukan kekerasan atau ancaman kekerasan, memaksa, melakukan tipu muslihat, melakukan serangkaian kebohongan, atau membujuk".

\section{b. Gambaran Perkara Nomor 142/Pid.Sus/2018/PN Wno. (Perkara Persetubuhan Anak Penyandang Disabilitas Intelektual)}

Dalam perkara a quo, Terdakwa Bejo (nama samaran) adalah seorang laki-laki berusia 63 (enam puluh tiga) tahun yang masih memiliki hubungan keluarga dengan korban yaitu sebagai Pakde. Bejo telah melakukan persetubuhan dengan Anak Korban Ai (nama samaran) selama kurun waktu bulan Januari 2018 sampai dengan bulan Juni 2018, bertempat di rumah Bejo. Korban merupakan seorang perempuan penyandang disabilitas intelektual berusia 14 (empat belas) tahun (selanjutnya disebut sebagai anak korban). Dalam melakukan perbuatannya, Bejo membujuk anak korban dengan memberikan sejumlah uang dengan kisaran sebesar Rp2.000,00 (dua ribu rupiah) sampai dengan Rp5.000,00 (lima ribu rupiah), sehingga anak korban yang merupakan anak berkebutuhan khusus, mau mengikuti keinginan Bejo. Bejo juga mengancam akan menembak anak korban, apabila anak korban memberitahu kejadian tersebut kepada orang lain. Akibat perbuatan Bejo tersebut, anak korban mengalami sakit pada alat kelaminnya dan menyebabkan anak korban hamil.

Berdasar hasil wawancara, kasus tersebut terungkap ketika para Guru SLB 2 Playen melihat perubahan fisik anak korban seperti orang yang sedang hamil. Kemudian, para Guru berinisiatif untuk memeriksa urine seluruh siswa SLB 2 Playen, dimana anak korban menunjukkan hasil positif hamil. Atas kehamilan anak korban tersebut, para Guru membujuk anak korban bercerita mengenai kehamilannya, kemudian anak korban menjelaskan bahwa yang membuatnya hamil adalah Bejo (Pakde dari anak korban). Kemudian, pihak sekolah menyampaikan kejadian tersebut kepada orang tua anak korban. Selanjutnya, orang tua anak korban melaporkan kasus tersebut ke Polsek Playen. 
Sasana Inklusi dan Gerakan Advokasi Difabel (SIGAB) yang mendapat kabar kasus tersebut dari media cetak langsung menghubungi Polres Gunung Kidul. Setelah mendapat konfirmasi dan informasi dari Polres Gunung Kidul, SIGAB langsung bergerak menuju ke Polsek Playen untuk mendampingi anak korban. Langkah awal yang dilakukan SIGAB adalah membuat profil asesmen terhadap anak korban. Asesmen merupakan kegiatan pengumpulan informasi secara kuantitatif atau kualitatif melalui berbagai macam tes, pengamatan, serta teknik lain untuk menentukan performa seseorang (Gabel L. Dorothy L, 1994, dalam Talango, 2018).

Profil asesmen yang dilakukan oleh SIGAB dimulai dengan melakukan pendekatan dan berkomunikasi dengan anak korban, kemudian melakukan pemeriksaan di rumah sakit yang terakreditasi untuk memeriksa kondisi kehamilan, kejiwaan dan kesehatan anak korban. Profil asesmen tersebut dilakukan untuk mempersiapkan langkah-langkah apa saja yang perlu dilakukan oleh SIGAB untuk mendampingi anak korban. Selanjutnya, SIGAB mengajukan surat permohonan perlindungan terhadap anak korban kepada Lembaga Perlindungan Saksi dan Korban (LPSK).

Dalam pemeriksaan anak korban di tahap penyidikan, anak korban didampingi oleh SIGAB, dan orang tua anak korban. Pemeriksaan dilakukan secara mengalir, karena Penyidik sudah mendapat informasi dari SIGAB atas profil asesmen anak korban. Jika diperlukan, dalam memeriksa anak korban digunakan alat peraga atau gambar untuk mempermudah anak korban mengingat peristiwa yang menimpanya, karena ingatan anak korban sebagai penyandang disabilitas intelektual memiliki keterbatasan. Kemudian, selain melakukan rekonstruksi versi pelaku, rekontruksi juga dilakukan berdasarkan versi korban agar mendapat cerita yang lebih utuh.

Alam rekontruksi versi korban, Jaksa (yang nantinya menjadi Penuntut Umum dalam persidangan perkara a quo) juga dilibatkan, hal tersebut bertujuan supaya anak korban ketika diperiksa dalam persidangan sudah mengetahui/mengenali Penuntut Umum tersebut. Karena, penyandang disabilitas intelektual harus mempercayai lawan bicaranya, jika belum percaya maka proses pemeriksaan persidangan akan mengalami kesulitan. Proses rekontruksi versi korban tersebut didokumentasikan dan nantinya akan ditunjukkan kembali dalam persidangan oleh Penuntut Umum untuk mengkonfirmasi keterangan atau suatu peristiwa kepada anak korban. Hal tersebut dilakukan supaya anak 
korban tidak mengulang kembali apa yang telah ia sampaikan sebelumnya, karena dapat menimbulkan trauma bagi anak korban.

Dalam persidangan, Penuntut Umum mendakwa terdakwa dengan dakwan alternatif, kesatu: Pasal 81 ayat (1) jo Pasal 76D, atau kedua: Pasal 81 ayat (2) jo Pasal 76D Undang-Undang Nomor 17 Tahun 2016 tentang Penetapan Peraturan Pemerintah Pengganti Undang-Undang Nomor 1 Tahun 2016 tentang Perubahan Kedua Atas Undang-Undang Nomor 23 Tahun 2002 tentang Perlindungan Anak jo Pasal 65 ayat (1) KUHP. Kemudian, dalam proses pembuktian Penuntut Umum juga menghadirkan Ahli Psikolog dari LSM Rifka Annisa Yogyakarta. Ahli tersebut menyampaikan bahwa anak korban mengalami keterbatasan mental sedang, dengan skor IQ sebesar 50.

Dalam perkara a quo, hak anak korban telah diakomodasi oleh Pasal 5 ayat (1) UU Nomor 31 / 2014 tentang Perubahan Atas UU Nomor 13 / 2006 tentang Perlindungan Saksi dan Korban. Hak anak korban yang berkaitan langsung dan terealisasikan yaitu: memberikan keterangan tanpa tekanan, bebas dari pertanyaan yang menjerat, dirahasiakan identitasnya, dan mendapat pendamping.

Hak mendapat restitusi pada dasarnya telah diupayakan oleh SIGAB melalui surat permohonan restitusi yang diajukan ke LPSK, kemudian LPSK melalui Surat LPSK Nomor R-929/1.5.1.HSMPP/LPSK/11/2018 tanggal 26 November 2018 telah merinci dan menyampaikan besaran nilai restitusi yaitu sebesar Rp12.418.000,00 (dua belas juta empat ratus delapan belas ribu rupiah) yang harus dibayarkan oleh terdakwa kepada anak korban. Surat LPSK tersebut diajukan kepada Penuntut Umum pada proses persidangan dan kemudian dimuat dalam Surat Tuntutan Penuntut Umum.

"Dengan sengaja membujuk Anak Korban melakukan persetubuhan dengannya" sebagaimana dakwaan alternatif kedua Pasal 81 ayat (2) jo. Pasal 76D. Kemudian, Majelis Hakim menjatuhkan Putusan pidana terhadap terdakwa dengan pidana penjara selama 13 (tiga belas) tahun dan pidana denda Rp200.000.000,00 (dua ratus juta rupiah), dengan ketentuan apabila pidana denda tersebut tidak dibayar diganti dengan kurungan selama 2 (dua) bulan dan memerintahkan terdakwa membayar restitusi sejumlah Rp12.418.000,00 (dua belas juta empa ratus delapan belas ribu rupiah) sebagaimana tertuang dalam Surat dari LPSK Nomor R-929/1.5.1.HSMPP/LPSK/11/2018 tanggal 26 November 2018 paling lama 30 (tiga puluh) hari sejak menerima salinan Putusan Pengadilan berita acara pelaksanaan Putusan Pengadilan, serta menetapkan apabila 
terdakwa tidak dapat membayar restitusi tersebut maka diganti dengan kurungan selama 3 (tiga) bulan. ${ }^{1}$ Namun, hingga batas waktu pembayaran restitusi yang telah di tetapkan, terdakwa tidak membayar restitusi tersebut. Dengan demikian, hak anak korban mendapat restitusi belum terealisasikan.

Selain mendapat hak korban sebagaimana diatur dalam UU Nomor 31 / 2014 tentang Perubahan atas UU Nomor 13 / 2006 tentang Perlindungan Saksi dan Korban, anak korban juga mendapat hak perlindungan khusus sebagaimana diatur dalam Pasal 69A Undang-Undang Nomor 35 Tahun 2014 tentang Perubahan Atas Undang-Undang Nomor 23 Tahun 2002 tentang Perlindungan Anak, yaitu:

1) Edukasi tentang kesehatan reproduksi, nilai agama, dan nilai kesusilaan

Edukasi tersebut dilakukan oleh Pusat Pelayanan Terpadu Pemberdayaan Perempuan dan Anak (P2TP2A) Kabupaten Gunung Kidul;

2) Rehabilitasi sosial

3) Rehabilitasi tersebut dilakukan dengan cara berdialog dengan pihak SLB 2 Playen supaya anak korban dapat diterima kembali ke Sekolah. Karena ketika kasus yang menimpa anak korban terungkap, anak korban dikeluarkan dari SLB 2 Playen.

4) Pendampingan psikososial pada saat pengobatan sampai pemulihan Pendampingan psikososial tersebut dilakukan oleh P2TP2A Kabupaten Gunung Kidul dan Puskesmas daerah setempat;

5) Pemberian perlindungan dan pendampingan pada setiap tingkat pemeriksaan mulai dari penyidikan, penuntutan, sampai dengan pemeriksaan di sidang pengadilan Perlindungan dan pendampingan hukum anak korban pada setiap tahap pemeriksaan dilakukan oleh SIGAB.

\section{Penerapan Peraturan Perundang-Undangan dalam Perkara Nomor 78/Pid.B/2013/PN Ska. dan Perkara Nomor 79/Pid.B/2013/PN Ska. dengan Perkara Nomor 142/Pid. Sus/2018/PN Wno.}

Berdasarkan gambaran dua perkara yang telah diuraikan tersebut di atas, terdapat perbedaan antara perkara Nomor 78/Pid.B/2013/PN Ska. dan Perkara Nomor 79/Pid.B/2013/PN Ska. (perkara Korban Ica) dengan perkara Nomor 142/Pid.Sus/2018/PN

\footnotetext{
${ }^{1}$ Putusan Nomor 142/Pid.Sus/2018/PN Wno., hlm. 32-33.
} 
Wno. (perkara Anak Korban Ai). Perbedaan antara Perkara Korban Ica dan Anak Korban Ai tersebut terlihat jelas pada Peraturan Perundang-undangan yang mengatur rumusan tindak pidana masing-masing perkara tersebut, serta pemahaman Penyidik, Jaksa/Penuntut Umum dan Hakim dalam menangani kasus dengan korban penyandang disabilitas. Peraturan Perundang-undangan yang ada saat ini belum cukup melindungi penyandang disabilitas dari tindak pidana asusila terkait perkosaan dan pencabulan. Dalam KUHP, tindak pidana perkosaan dan pencabulan harus memenuhi unsur "dengan kekerasan atau ancaman kekerasan memaksa seseorang", sedangkan dalam Undang-Undang tentang Perlindungan Anak pada Pasal perkosaan dan pasal pencabulan terhadap anak terdapat unsur yang bersifat alternatif yaitu: "melakukan kekerasan atau ancaman kekerasan, memaksa, melakukan tipu muslihat, melakukan serangkaian kebohongan, atau membujuk."

Adanya perbedaan unsur dalam pasal perkosaan dan pencabulan dalam KUHP dengan Undang-Undang tentang Perlindungan Anak menyebabkan penyandang disabilitas dewasa lebih dirugikan ketika menjadi korban perkosaan atau pencabulan. Karena dalam setiap kasus persetubuhan terhadap penyandang disabilitas dewasa, belum tentu terdapat unsur "dengan kekerasan atau ancaman kekerasan memaksa seseorang" yang dapat digunakan untuk menjerat pelaku dengan tindak pidana perkosaan atau pencabulan. Terlebih dengan sedikitnya hak korban yang diperoleh dalam KUHP.

Selain itu, hak korban dalam Undang-Undang tentang Perlindungan Saksi dan Korban juga hanya diberikan kepada korban tindak pidana tertentu, antara lain: tindak pidana pelanggaran hak asasi manusia yang berat, tindak pidana korupsi, tindak pidana pencucian uang, tindak pidana terorisme, tindak pidana perdagangan orang, tindak pidana narkotika, tindak pidana psikotropika, tindak pidana seksual terhadap anak dan tindak pidana lain yang mengakibatkan posisi saksi dan/atau korban dihadapakan pada situasi yang sangat membahayakan jiwanya. Dengan demikian, dalam konteks penyandang disabilitas sebagai korban tindak pidana asusila, maka yang termasuk dalam tindak pidana tertentu tersebut adalah "tindak pidana seksual terhadap anak".

Selanjutnya, belum adanya pemahaman yang sama dari Penyidik, Jaksa/Penuntut Umum dan Hakim mengenai kondisi penyandang disabilitas menyebabkan penanganan setiap kasus yang melibatkan penyandang disabilitas sebagai korban tindak pidana (korban difabel) mengalami hambatan. Saat ini aparat penegak hukum dalam setiap proses pemeriksaan bergantung pada Organisasi atau Lembaga Difabel dalam menangani kasus 
yang melibatkan penyandang disabilitas. Apabila korban difabel tidak mendapat pendampingan, maka haknya tidak dapat dilindungi dengan baik.

Perlindungan hukum yang dapat diberikan kepada penyandang disabilitas korban tindak pidana asusila terkait perkosaan-pencabulan, yaitu sebagai berikut:

a. Berdasarkan KUHAP:

Pada Pasal 178, yaitu: mendapat penerjemah bahasa isyarat. Kemudian, pada Pasal 160, yaitu: yang diperiksa pertama sebagai saksi adalah korban (saksi korban).

b. Berdasarkan Undang-Undang Nomor 8 Tahun 2016 tentang Penyandang Disabilitas

c. Pada Pasal 9, hak keadilan dan perlindungan hukum untuk penyandang disabilitas meliputi hak:

1) Mendapat perlakuan yang sama di hadapan hukum;

2) Diakui sebagai subjek hukum;

3) Memperoleh penyediaan aksesibilitas dalam pelayanan peradilan.

Kemudian, pada Pasal 30, yaitu: sebelum diperiksa penegak hukum wajib mendapat pertimbangan atau saran dari dokter atau tenaga kesehatan lainnya mengenai kondisi kesehatan, psikolog atau psikiater mengenai kondisi kejiwaan; dan/atau pekerja sosial mengenai kondisi psikososial. Selanjutnya, pada Pasal 31, yaitu: ketika pemeriksaan terhadap anak penyandang disabilitas, Penegak Hukum wajib mengizinkan orang tua, pendamping dan penerjemah untuk mendampingi anak tersebut.

d. Berdasarkan Undang-Undang Nomor 31 Tahun 2014 tentang Perubahan Atas Undang-Undang Nomor 13 Tahun 2006 tentang Perlindungan Saksi dan Korban. Pada Pasal 5 ayat (1) menyatakan bahwa saksi dan korban berhak:

1) Memperoleh perlindungan atas keamanan dan pribadi, Keluarga, dan harta bendanya, serta bebas dari Ancaman yang berkenaan dengan kesaksian yang akan, sedang, atau telah diberikannya;

2) Ikut serta dalam proses memilih dan menentukan bentuk perlindungan dan dukungan keamanan;

3) Memberikan keterangan tanpa tekanan;

4) Mendapat penerjemah;

5) Bebas dari pertanyaan yang menjerat;

6) Mendapat informasi mengenai perkembangan kasus;

7) Mendapat informasi mengenai putusan pengadilan; 
8) Mendapat informasi dalam hal terpidana dibebaskan;

9) Dirahasiakan identitasnya;

10) Mendapat identitas baru;

11) Mendapat tempat kediaman sementara;

12) Mendapat tempat kediaman baru;

13) Memperoleh penggantian biaya transportasi sesuai dengan kebutuhan;

14) Mendapat nasihat hukum;

15) Memperoleh bantuan biaya hidup sementara sampai batas waktu Perlindungan berakhir; dan/atau mendapat pendampingan.

Kemudian, pada Pasal 6 ayat (1) menyatakan bahwa korban tindak pidana kekerasan seksual juga berhak mendapatkan:

1) Bantuan medis;

2) Bantuan rehabilitasi psikososial dan psikologis.

Selanjutnya, pada Pasal 7A menyatakan bahwa korban tindak pidana berhak mendapat restitusi berupa: ganti kerugian atas kehilangan kekayaan atau penghasilan, ganti kerugian yang ditimbulkan akibat penderitaan yang berkaitan langsung sebagai akibat tindak pidana, dan/atau penggantian biaya perawatan medis dan/atau psikologis.

Dalam konteks penyandang disabilitas sebagai korban tindak pidana asusila, hak sebagaimana dimaksud pada Pasal 5 ayat (1) diberikan dalam perkara tindak pidana seksual terhadap anak penyandang disabilitas. Oleh karena itu, apabila korban merupakan orang dewasa maka hak korban pada Pasal 5 ayat (1) tersebut tidak dapat direalisasikan dengan baik, dan harus mengacu pada Peraturan Perundang-undangan lain yang mengatur hak korban secara umum dan hak penyandang disabilitas berhadapan dengan hukum.

e. Berdasarkan Undang-Undang Nomor 35 Tahun 2014 tentang Perubahan Atas Undang-Undang Nomor 23 Tahun 2002 tentang Perlindungan Anak (Sebagaimana diubah dengan Undang-Undang Nomor 17 Tahun 2016 tentang Penetapan Peraturan Pemerintah Pengganti Undang-Undang Nomor 1 Tahun 2016 tentang Perubahan Kedua Atas Undang-Undang Nomor 23 Tahun 2002 tentang Perlindungan Anak):

Pada Pasal 64 menyatakan bahwa perlindungan khusus bagi Anak yang berhadapan dengan hukum dilakukan melalui: 
1) Perlakuan secara manusiawi dengan memperhatikan kebutuhan sesuai dengan umurnya;

2) Pemberian bantuan hukum dan bantuan lain secara efektif;

3) Penghindaran dari publikasi atas identitasnya;

4) Pemberian aksesibilitas, terutama bagi Anak Penyandang Disabilitas.

Kemudian, pada 69A menyatakan bahwa perlindungan khusus bagi Anak Korban kejahatan seksual dilakukan melalui upaya:

1) Edukasi tentang kesehatan reproduksi, nilai agama, dan nilai kesusilaan;

2) Rehabilitasi sosial;

3) Pendampingan psikososial pada saat pengobatan sampai pemulihan;

4) Pemberian perlindungan dan pendampingan pada setiap tingkat pemeriksaan mulai dari penyidikan, penuntutan, sampai dengan pemeriksaan di sidang pengadilan.

Selanjutnya, pada Pasal 70 menyatakan bahwa perlindungan khusus bagi Anak penyandang disabilitas dilakukan melalui upaya:

1) Perlakuan Anak secara manusiawi sesuai dengan martabat dan Hak Anak;

2) Pemenuhan kebutuhan khusus;

3) Perlakuan yang sama dengan Anak lainnya untuk mencapai integrasi sosial sepenuh mungkin dan pengembangan individu;

4) Pendampingan sosial.

f. Pemenuhan Hak yang Berkaitan Langsung dengan Korban Difabel

Pada dasarnya terdapat hak penyandang disabilitas yang berkaitan secara langsung dengan korban difabel. Saat hak tersebut terpenuhi, maka proses Peradilan bisa berjalan secara fair (Syafi'ie, Purwanti, and Ali, 2016). Hak tersebut antara lain:

1) Hak untuk mendapat pendamping;

2) Hak untuk mendapatkan penerjemah;

3) Hak untuk mendapatkan Ahli;

4) Hak untuk diperiksa oleh Penyidik, Penuntut Umum dan Hakim yang memahami masalah difabel;

5) Hak untuk mendapatkan pertanyaan yang tidak menjerat atau merendahkan sifat dasar difabel; 
6) Hak untuk diberitahu perkembangan kasus yang sedang ditangani penyidik, jaksa, dan hakim;

7) Hak untuk mendapatkan informasi tentang putusan yang dijatuhkan Hakim kepada terdakwa.

\section{Peran Sasana Inklusi dan Gerakan Advokasi Difabel dalam Proses Advokasi Terhadap Penyandang Disabilitas Korban Tindak Pidana Asusila}

Sasana Inklusi dan Gerakan Advokasi Difabel (SIGAB) sebagai Pendamping memiliki peran dalam proses advokasi terhadap penyandang disabilitas sebagai korban tindak pidana, dimana advokasi tersebut terdiri dari beberapa langkah (Purwanti, Zulhendra, and Syafiie 2017). Langkah-langkah tersebut, yaitu sebagai berikut:

a. Langkah Pertama: Menyusun Profil Asesmen

Tahap awal dari menyusun profil asesmen adalah perkenalan. Tim dari SIGAB memperkenalkan diri berdasarkan standar perkenalan yang menjelaskan misi dan prosedur Lembaga. Tujuan menyusun profil asesmen adalah:

1) Mengetahui kondisi korban difabel serta kebutuhan-kebutuhan terkait dengan aksesibilitas;

2) Memberikan informasi tentang korban difabel kepada aparat penegak hukum dan stakeholder yang akurat dan bisa dipertanggungjawabkan secara hukum;

3) Pembuktian hukum bahwa korban difabel bisa menjadi penyebab ketidakberdayaan seseorang untuk melawan tindak kekerasan yang menimpanya;

4) Mengetahui traumatik yang dialami korban difabel, termasuk perubahan perilaku yang terjadi pada korban difabel setelah terjadinya tindak pidana;

5) Mengetahui strategi atau cara berkomunikasi yang efektif kepada korban difabel yang didampingi.

Dalam menyusun profil asesmen korban difabel harus melibatkan orang yang profesional di bidangnya, seperti psikolog, dokter, psikiater, dan sebagainya. Profil asesmen harus dilengkapi dengan bukti-bukti pendukung yang berlegalitas dari ahli, seperti rekam medis, surat keterangan tentang hasil pemeriksaan, ahli jiwa, serta surat keterangan kondisi mental korban.

b. Langkah Kedua: Mendengar Cerita dan Menyusun Kronologi Kasus 
Strategi yang dapat digunakan dalam mendengar cerita dari korban difabel kemudian menyusun kronologi kasus antara lain:

1) Mendengarkan cerita korban difabel dan pengalamannya;

2) Bertanya kepada korban difabel hasil apa yang diharapkan dari pengampingan;

3) Selama pembicaraan dengan korban difabel, pendamping harus mengumpulkan informasi penting untuk memutuskan langkah-langkah apa saja yang dapat dilakukan;

4) Mencatat jenis penyiksaan dan eksploitasi yang dialami korban difabel dan buktibukti bahwa korban difabel telah mengalami penyiksaan tersebut. Informasi ini akan menentukan langkah hukum apa yang terbaik untuk kasus tersebut;

5) Memberitahu korban difabel mengenai langkah selanjutnya dalam proses ini;

6) Pendamping memberikan informasi mengenai langkah-langkah hukum yang dapat ditempuh terhadap kasus yang dialami korban difabel;

7) Pendamping dalam melakukan langkah hukum harus berdasarkan dari kebutuhan dan kepentingan korban difabel;

8) Pendamping harus teliti dan berhati-hati dalam menentukan sikap, memilih dan memilah apabila terdapat pihak yang mengatasnamakan korban difabel demi kepentingan pribadinya.

c. Langkah Ketiga: Menganalisa Kasus

Proses analisa tersebut dilakukan dengan:

1) Mendiskusikan kasus bersama dengan tim;

2) Menjaga privasi korban difabel;

3) Mengkaji ulang penyiksaan dan eksploitasi yang diderita oleh korban difabel;

4) Membicarakan pilihan korban difabel terhadap kasus tersebut;

5) Menganalisa dan mendiskusikan berbagai langkah hukum yang relevan terhadap kasus. Kemudian mempertimbangkan faktor lain seperti lama waktu dalam menyelesaikan kasus, biaya dan kemungkinan menang;

6) Membahas kesulitan atau hambatan yang mungkin muncul;

7) Membahas jenis dan besaran bantuan yang dapat diberikan kepada korban difabel;

8) Mempertimbangkan dan membicarakan layanan rujukan yang bisa didapatkan oleh korban difabel. 
d. Langkah Keempat: Mengkaji Ulang Langkah Hukum

Proses pengkajian langkah hukum dilakukan dengan:

1) Membicarakan langkah hukum yang ada kepada korban difabel berdasarkan fakta kasusnya, dan membicarakan semua pilihan langkah yang ada;

2) Membicarakan hal-hal penting seperti: hasil yang mungkin didapat dari setiap pilihan, peran korban difabel dalam proses (aspek positif dan negatif setiap proses hukum), perkiraan lama waktu pada masing-masing langkah hukum, biaya yang diperlukan pada setiap langkah hukum, serta menjelaskan hal apa yang dapat dan tidak dapat diberikan oleh pendamping;

3) Memastikan korban difabel memahami bahwa akses yang dia miliki terhadap layanan tersebut tidak bergantung pada langkah hukum apa yang diambil;

4) Mengkaji ulang semua pilihan yang ada;

5) Bersikap profesional dalam setiap langkah hukum yang akan diambil.

e. Langkah Kelima: Mendampingi Korban Difabel Selama Proses Advokasi Litigasi dan Non Litigasi

Dalam proses peradilan, sebaiknya korban difabel tidak melaui proses peradilan tersebut sendirian. Pendamping membantu korban difabel dengan melibatkan: penerjemah atau juru bahasa dan Ahli. Bantuan yang diberikan pendamping kepada korban difabel dapat mencakup:

1) Memberikan keterangan mengenai proses hukum kepada korban difabel dan keluarganya;

2) Membantu korban difabel untuk mengakses proses peradilan;

3) Memberikan dorongan dan dukungan emosional;

4) Mendampingi korban difabel untuk mengumpulkan dokumen dan/atau bukti-bukti yang diperlukan untuk pemeriksaan atau pembuktian;

5) Jika korban difabel buta huruf atau mengalami hambatan komunikasi, pendamping membantu menjelaskan, membaca dan menuliskan keterangan terkait kasusnya;

6) Bertindak sebagai sumber rujukan kepada layanan lainnya, seperti penasihat hukum, layanan medis, psikologis, ahli dan pendidikan;

7) Memberikan bantuan akomodasi, biaya perkara, dan biaya transportasi (apabila korban difabel tidak mampu); 
8) Mendampingi korban difabel dalam setiap tahap pemeriksaan (penyidikan sampai dengan persidangan).

\section{KESIMPULAN}

Pertama, penerapan Peraturan Perundang-undangan terhadap Perkara Korban Ica dan Anak Korban Ai terdapat perbedaan, yaitu: perbedaan pada Peraturan Perundang-undangan yang mengatur rumusan tindak pidana masing-masing perkara tersebut. Dalam KUHP, tindak pidana perkosaan dan pencabulan harus memenuhi unsur "dengan kekerasan atau ancaman kekerasan memaksa seseorang", sedangkan dalam Undang-Undang tentang Perlindungan Anak pada Pasal perkosaan dan Pasal pencabulan terhadap anak terdapat unsur yang bersifat alternatif yaitu: "melakukan kekerasan atau ancaman kekerasan, memaksa, melakukan tipu muslihat, melakukan serangkaian kebohongan, atau membujuk." Adanya perbedaan unsur dalam Pasal perkosaan dan pencabulan dalam KUHP dengan Undang-Undang tentang Perlindungan Anak tersebut menyebabkan penyandang disabilitas dewasa lebih dirugikan ketika menjadi korban perkosaan dan pencabulan. Selanjutnya, belum adanya pemahaman yang sama dari Penyidik, Jaksa/Penuntut Umum dan Hakim mengenai kondisi penyandang disabilitas menyebabkan penanganan setiap kasus yang melibatkan penyandang disabilitas sebagai korban tindak pidana mengalami hambatan.

Kedua, perlindungan hukum terhadap penyandang disabilitas korban tindak pidana asusila terkait perkosaan dan pencabulan dapat dilakukan dengan pemenuhan hak yang berkaitan langsung dengan korban difabel, yaitu: hak untuk mendapat pendamping, hak untuk mendapatkan penerjemah, hak untuk mendapatkan Ahli, hak untuk diperiksa oleh Penyidik, Penuntut Umum dan Hakim yang memahami masalah difabel, hak untuk mendapatkan pertanyaan yang tidak menjerat atau merendahkan sifat dasar difabel, hak untuk diberitahu perkembangan kasus yang sedang ditangani Penyidik, Jaksa, dan Hakim, serta hak untuk mendapatkan informasi tentang putusan yang dijatuhkan Hakim kepada terdakwa.

Ketiga, peran Sasana Iklusi dan Gerakan Advokasi Difabel dalam advokasi penyandang disabilitas korban tindak pidana asusila terkait perkosaan dan pencabulan yaitu dengan cara: menyusun profil asesmen korban difabel, mendengar cerita korban difabel dan menyusun kronologi kasus, menganalisa kasus, mengkaji ulang langkah hukum, serta mendampingi korban difabel selama proses Litigasi dan Non Litigasi. 


\section{REFERENSI}

Alfian, Alfan. 2015. "Perlindungan Hukum Terhadap Kaum Difabel Korban Pemerkosaan." 9:629-42.

Amin, Muhammad, and Mustari. 2015. "Pemenuhan Hak-Hak Penyandang Tuna Daksa Untuk Mendapatkan Pendidikan Dan Pelatihan Keterampilan (Studi Panti Sosial Bina Daksa Wirajaya Makasar)." Jurnal Pemikiran, Penelitian Hukum, Pendidikan Pancasila Dan Kewarganegaraan II:82-95.

Ashar, Dio, Bestha Inatsan Ashila, and Gita Nadia Pramesa. 2019. Panduan Penanganan Perkara Penyandang Disabilitas Berhadapan Dengan Hukum. edited by M. J. Y. Theodora Yuni Shah Putri. Jakarta: Masyarakat Pemantau Peradilan Indonesia Fakultas Hukum Universitas Indonesia (MaPPI FHUI) bekerjasama dengan Australia Indonesia Partnership for Justice 2 (AIPJ 2).

Conroy, P. 2015. "Commission to Inquire into Child Abuse - Was There Hate Crime Against Children with Disabilities?" Irish Journal of Legal Studies 5(1):5-21.

Dimyati, Khudzaifah, and Kelik Wardiono. 2004. Metode Penelitian Hukum. Surakarta: Fakultas Hukum Universitas Muhammadiyah Surakarta.

Endang Ekowarni. 2014. "Difabel Masih Terdiskriminasi Di Depan Hukum.” Jurnal Difabel 1:7-9.

Purwanti, Saro Zulhendra, and Moh. Syafiie. 2017. Panduan Paralegal Pendampingan Kasus Difabel Berhadapan Dengan Hukum. edited by P. Indrawan. Yogyakarta: SIGAB (Sasana Integrasi dan Advokasi Difabel).

Reiter, Shunit, Diane N. Bryen, and Ifat Shachar. 2007. "Adolescents with Intellectual Disabilities as Victims of Abuse." Journal of Intellectual Disabilities 11(4):371-87.

Saija, F. Willem. 2017. Eksistensi Dan Urgensi Penerjemah Bahasa Isyarat "Bisu Tuli" Dalam Melancarkan Proses Peradilan Pidana. Jakarta: Puslitbang Hukum dan Peradilan Mahkamah Agung RI.

Syafi'ie, M., Purwanti, and Mahrus Ali. 2016. Potret Difabel Berhadapan Dengan Hukum Negara. edited by P. Windrawan. Yogyakarta: SIGAB (Sasana Integrasi dan Advokasi Difabel).

Talango, Sitti R. 2018. “Asesmen Perkembangan Anak ( Studi Kasus Asesmen Perkembangan Anak Usia 2 Tahun ).” 6.

Peraturan Perundang-undangan

Undang-Undang Dasar Negara Republik Indonesia Tahun 1945

Kitab Undang-Undang Hukum Acara Pidana

Kitab Undang-Undang Hukum Pidana

Undang-Undang Republik Indonesia Nomor 8 Tahun 2016 tentang Penyandang Disabilitas

Undang-Undang Republik Indonesia Nomor 31 Tahun 2014 tentang Perubahan Atas UndangUndang Nomor 13 Tahun 2006 tentang Perlindungan Saksi dan Korban

Undang-Undang Republik Indonesia Nomor 35 Tahun 2014 tentang Perubahan Atas UndangUndang Nomor 23 Tahun 2002 tentang Perlindungan Anak

Putusan Pengadilan:

Putusan Nomor 142/Pid.Sus/2018/PN Wno.

Putusan Nomor 79/Pid.B/2013/PN Ska.

Putusan Nomor 78/Pid.B/2013/PN Ska. 
JURNAL JURISPRUDENCE

Vol. 10, No. 1, 2020, pp.73-93

p-ISSN: $1829-5045$; e-ISSN : 2549-5615

Website: http://journals.ums.ac.id/index.php/jurisprudence

Wawancara

Purwanti. Koordinator Advokasi dan Jaringan Sasana Inklusi dan Gerakan Advokasi Difabel (SIGAB). Wawancara. Sleman. 23 Desember 2019. 